\title{
SHORELINES OF THE HOLOCENE MEGALAKE CHAD (AFRICA, SAHARA) INVESTIGATED WITH VERY HIGH RESOLUTION SATELLITE IMAGERY (PLEIADES): EXAMPLE OF THE GOZ KERKI PALEO-SPIT
}

\author{
Mathieu Schuster ${ }^{1}$, Claude Roquin ${ }^{1}$, Arnaud Durand ${ }^{2}$, Abderamane Moussa ${ }^{3}$, Jean-François Ghienne ${ }^{1}$, Bernard \\ Allenbach $^{2}$, Philippe Duringer ${ }^{1}$, Frédéric Bouchette ${ }^{4}$ \\ 1 : Institut de Physique du Globe de Strasbourg, UMR7516, CNRS - Université de Strasbourg/EOST, 1 rue Blessig, \\ 67084 Strasbourg Cedex, France, mschuster@unistra.fr \\ 2 : SERTIT, Université de Strasbourg, 300 Boulevard Sébastien Brandt, 67412 Illkirch-Graffenstaden, France \\ 3 : Département de Géologie et Paléontologie, Faculté des Sciences, Université de N'Djamena, Tchad \\ 4 : Géosciences-Montpellier CNRS / Université Montpellier II 34095 Montpellier 5, France
}

\begin{abstract}
Résumé
Le Mégalac Tchad, avec une superficie d'environ $350000 \mathrm{~km}^{2}$, est le plus vaste des paléo-lacs du Sahara-Sahel et constitue l'un des marqueurs les plus emblématiques des changements hydroclimatiques qui se sont produits durant la Période Humide Africaine (PHA ; ca. 11,500 - 5,000 years BP) en Afrique subtropicale. Sur le terrain, l'existence du Mégalac Tchad est attestée par de vastes étendues de dépôts sédimentaires lacustres. Toutefois, compte tenu de sa très grande taille, ce paléo-lac est globalement mieux appréhendé à partir d'images synoptiques obtenues depuis l'espace. En effet, de remarquables structures littorales fossiles s'étirant sur plusieurs centaines de kilomètres sont clairement visibles sur des images satellites de seconde génération et représentent des archives majeures du Mégalac Tchad et du climat durant la PHA. Dans cette première étude du paléo-littoral du Mégalac à l'aide de l'imagerie satellite à très haute résolution, une scène Pléiades (image et MNT) a été utilisée afin de caractériser la flèche sableuse fossile du Goz Kerki, qui est l'une des structures littorales les plus représentatives et les mieux préservées de ce paléolac. À partir du couple stéréoscopique Pléiades la géomorphologie et la lithologie de cette paléo-flèche peuvent maintenant être détaillées et l'évolution de la paléo-bathymétrie du Mégalac Tchad est analysée plus précisément. Cette approche apporte de nouvelles données quant aux paléo-environnements et paléo-climats du Sahara-Sahel.
\end{abstract}

Mots-clés : période humide africaine, crêtes de plage, paléo-lac, littoral, scènes Pléiades

\begin{abstract}
Megalake Chad $\left(350,000 \mathrm{~km}^{2}\right)$, the largest paleo-lake of the Sahara-Sahel area, is one of the most emblematic marker of the hydroclimatic changes that occurred during the African Humid Period (AHP; ca. 11,500 - 5,000 years BP) in subtropical Africa. From field surveys, the existence of Megalake Chad is well demonstrated by widespread typical lake deposits. However, considering the very large size of this paleo-lake, it is best evidenced and understood from space. Conspicuous paleo-littoral features distributed along hundreds of kilometers are clearly visible on second generation satellite images. These features represent major archives of the Megalake Chad and of the climate during the AHP. This paper is the first attempt to investigate the paleo-littoral of Megalake Chad with very high resolution satellite imagery. A Pléiades scene (images and DEM) is used to characterize the fossil sand spit of the Goz Kerki, which is one of the most representative and best preserved littoral features of Megalake Chad. Thanks to Pléiades stereoscopic images the geomorphology and the lithology of this paleo-spit can now be detailed and the evolution of the paleo-bathymetry of Megalake Chad can be reconstructed. This brings new insights into the paleo-environments and paleo-climates of the Sahara-Sahel region.
\end{abstract}

Keywords: african humid period, beach ridges, paleo-lake, littoral, Pléiades scenes

\section{Introduction}

Lakes sediments are valuable continental archives of environments, ecosystems and climates (e.g., Cohen, 2003). Lake systems evolution is classically reconstructed from their central bottom deposits (i.e. coring) where continuous record is expected. However, alternative and complementary data can be brought from the study of their littoral zone, since lake shorelines directly reflect their spatial extent and hydrodynamics. Conversely, the identification of paleoshorelines from preserved landforms is of major interest for the restitution of the evolution of ancient lakes.
This study focuses on preserved shorelines morphosedimentary structures outlining Megalake Chad (Figure 1), a very large Holocene paleo-lake which developed during the climatic optimum of the African Humid Period (Schuster, 2002). During the last decade, satellite imagery proved a reliable tool to identify and characterize numerous shorelines features all around this paleo-lake (Ghienne et al., 2002 ; Schuster et al., 2005 ; Drake \& Bristow, 2006 ; Leblanc et al., 2006 ; Bouchette et al., 2010), although these studies are all based on rather low resolution data sets (Landsat, SRTM).

Here, we use a stereoscopic couple of very high resolution Pléiades images to characterize the paleo-spit of the Goz Kerki, which is one of the most 


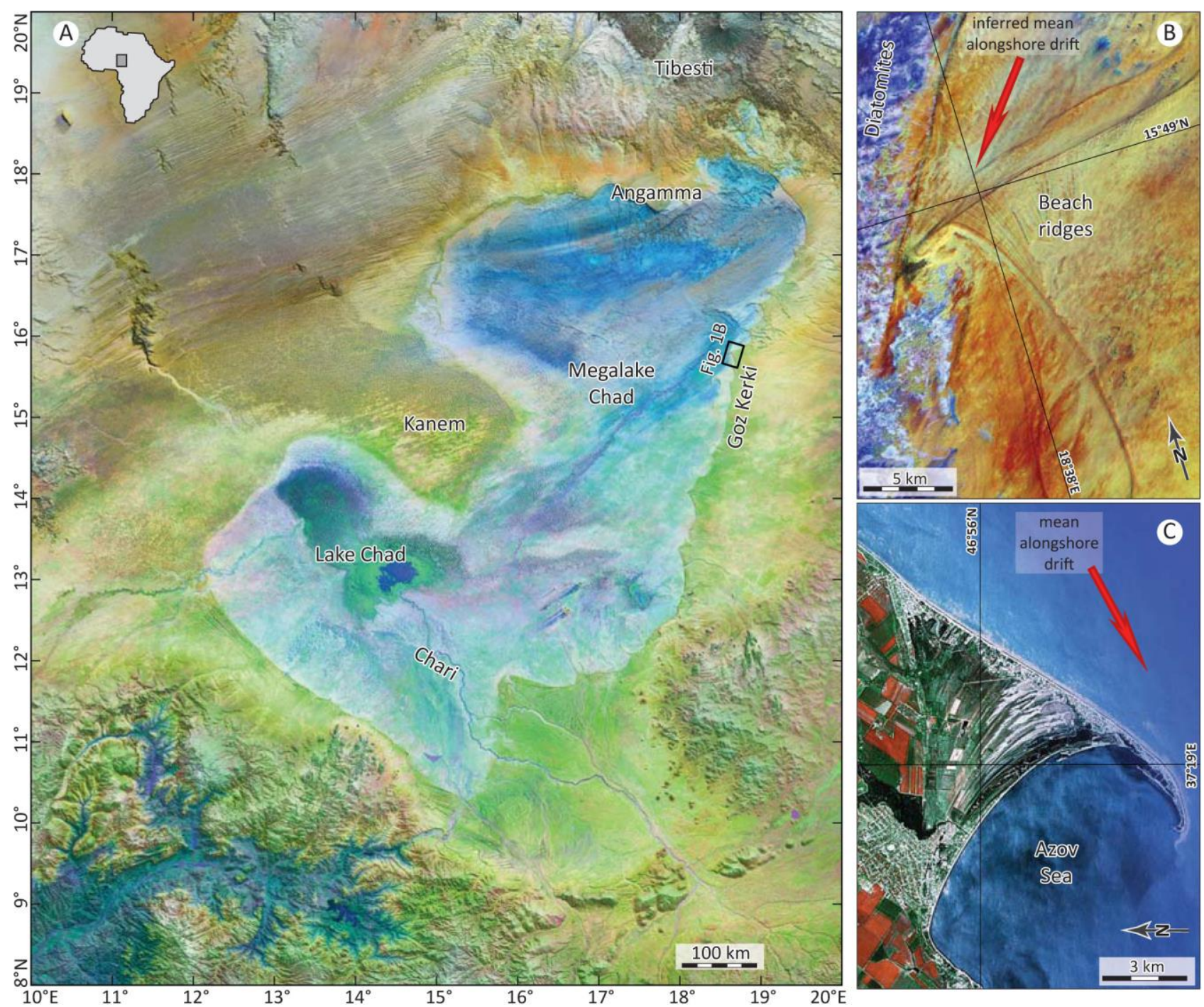

Figure 1: Location of the study area. (A) Geomorphological map of the Megalake Chad (based on SRTM3 and Landsat data). (B) The Goz Kerki paleo-spit seen with Landsat; note its typical shark fin outline shaped by the alongshore drift. (C) Modern spit for comparison (Belosarayskaya, Azov Sea). (B) and (C) modified from Bouchette et al. (2010).

representative large-scale littoral morphosedimentary feature of Megalake Chad.

\section{Study area and scientific background}

The Lake Chad Basin is the largest endoreic basin of Africa $\left(\sim 2,500,000 \mathrm{~km}^{2}\right)$, straddling Algeria, Cameroon, Central African Republic, Chad, Niger, Nigeria and Sudan. Its climate is controlled by the West African Monsoon System. This basin is subdivided into two sub-basin connected by the Bahr el Ghazal, an ancient overflow spillway northward of present-day Lake Chad. The northern sub-basin is presently inactive (i.e., Sahara desert) and the other one, to the South, corresponds to the watershed of Lake Chad which is mainly fed by the Chari-Logone river system. Lake Chad was once considered as the fourth largest permanent fresh water lake of Africa, but as a consequence of the severe droughts of the last decades, its size decreased drastically from $\sim 25,000$ $\mathrm{km}^{2}$ in the $1960^{\text {ies }}$ to $\sim 3,000 \mathrm{~km}^{2}$ today (Olivry et al., 1996).
Following the extreme aridity of the Last Glacial Maximum (ca. 20,000 years BP), the last major humid episode, induced by the orbital forcing on subtropical climate, is known as the (Holocene) African Humid Period (AHP; ca. 11,500 - 5,000 years BP) (e.g., deMenocal \& Tierney, 2012; Bard, 2013). Paleoenvironment changes in the Sahara during the AHP are notably marked by the reactivation of extinct river networks (e.g., Pachur \& Kröpelin, 1987; Paillou et al., 2009) and the development of lakes (e.g., Pachur \& Röttinger, 1997; Fabre \& Petit-Maire, 1988; Damnati, 2000; Gasse, 2000; Callot \& Fontugne, 2008; Kröpelin et al., 2008), identified by their geomorphological and sedimentological archives. In the same way, archeological archives reveal the temporary occupation of the Sahara by Man (e.g., Kuper, 2006; Sereno, 2008;) as well as by savannah fauna and flora (e.g., Le Quellec, 1999; Maley, 2004; Lézine, 2009). In the Chad Basin, this climate optimum led to the development of a very large lake known as Megalake Chad (e.g., Schuster et al., 2009; Sepulchre et al., 2008 and 2009; Contoux et al., 2013) (Figure 1).

The Megalake Chad extended over more than $350,000 \mathrm{~km}^{2}$ (Figure 1). The idea of an ancient very 
large water body in the Chad basin was already suggested by Tilho (1925), but its outlines were only defined a few decades later from the identification of discontinuous sand ridges interpreted as ancient beaches (Pias \& Guichard, 1957; Schneider, 1967). An alternative interpretation of these sand ridges as being neotectonic features was then proposed, strongly questioning the existence of the Megalake Chad (Durand, 1995). During the last decade this hypothesis was contradicted by both remote sensing (Ghienne et al., 2002; Schuster et al., 2005; Leblanc et al., 2006; Drake \& Bristow, 2006; Schuster et al., 2009; Bouchette et al., 2010) and field evidences (Schuster et al., 2003). The identification of ancient beach ridges, spits, deltas and a wave-ravinement surface (Schuster et al., 2005) definitively demonstrates that the sand ridges are of littoral origin. Consequently, these paleo-littoral features were used to (1) to precisely delineate the shorelines of the Megalake Chad, (2) to highlight wind-driven hydrodynamics of waves and associated longshore drift as the dominant basin-scale processes for clastics redistribution, (3) to identify the northern extension of paleomonsoon precipitations, and (4) to infer prevailing paleo-wind regimes (Schuster et al., 2005; Bouchette et al., 2010). Among all the morphosedimentary littoral features of Megalake Chad, the paleo-spit of the Goz Kerki area (Figure 1) is surely one of the most typical and well-preserved (Schuster et al., 2005). A spit is a ridge of sediments, partly rising above the water-level, extending from the land and formed by alongshore drift (e.g., Evans, 1942; Pilkey et al., 2011). It is worth noting that the fossil spit of the Goz Kerki and the modern sandspit of Belosarayskaya (Azov Sea) have similar morphologies (Figure 1).

\section{Methodology}

The Goz Kerki paleo-spit is here investigated with a stereoscopic couple of Pléiades images (OCNES 2012, Airbus DS/ Spot Image) and a Digital Elevation Model generated with the software MicMac, using the rational function models converted in grid format. MicMac, developed at the IGN/MATIS laboratory under CeCILL$B$ license, is an image correlator based both on multiresolution and multi-correlation approach. The matching process, carried out over images pyramids of various resolutions, is done by the minimization of a global energy function when estimating the disparities along the epipolar lines (Pierrot-Deseilligny \& Paparoditis, 2006; Pierrot-Deseilligny, 2007). The robustness of the matching and the versatility of the tool makes it especially efficient for the generation of digital surface model using Pléiades-HR stereoscopic acquisitions.

\section{Results}

As expected, the high spatial resolution $(0.7 \mathrm{~m})$ of the Pléiades images allows a much better characterization and understanding of the ancient and modern sedimentary deposits exposed in the Goz Kerki area. Various types of eolian sand accumulations (granule ripples, sand sheets, migrating barchan dunes, nebkhas), internal stratification of diatomites, and postdepositional erosional features resulting from intermittent surface runoff and wind deflation can be clearly identified (Figure 2).
Furthermore, the morphology of the paleo-spit is much better characterized than before from combination of the optic images with the DEM, highlighting complementary radiometric and topographic features (Figures 2 and 3). The successive ridges and swales marking the paleo-spit strandplain progradation are clearly evidenced by their elevations. Their formation can be related to water level fluctuations of the Megalake Chad from its maximum high-stand at $325 \mathrm{~m}$, induced by alternating wet/dry climatic phases during the AHP. On Pléiades multispectral images the ridge crests stand out as wind reworked sand sheets alternating with the darker deflation surfaces of the swales, where vehicle tracks and granular mega-ripples (deflation lags) are well defined with the panchromatic resolution (Figure 2E). But the radiometric facies is not always typical, and the penultimate beach ridge along the spit-front (ridge (b) on Figure $3 \mathrm{E}$ ) is very similar to the swale-bottom surfaces. However the ridge morphology is clearly revealed by the stereoscopic Pléiades DEM.

From these observations the following scenario is proposed for the sedimentary record of Megalake Chad during the Holocene. Diatomites result from biogenic accumulations in the offshore zone while beach ridges were nourished by alongshore drift redistribution of clastics in the littoral zone. The spit strandplain is composed of numerous narrow beach ridges of nearly constant elevation that record the successive highstand periods of the paleo-lake sustained by the AHP climatic optimum and regulated by the Benue Trough outlet to the South. The two last sand ridges (ridges (a) and (b), Figure 3E) at lower elevations mark the end of the AHP and the onset of the lake regression forced by the deterioration of the climate. Post-lake erosional processes by water and wind have not yet significantly affected the preservation of the Goz Kerki paleo-spit, but they provide some evidences of susequent short-lived pluvial episodes within a long-lasting arid phase.

\section{Conclusion and perspectives}

Preserved littoral landforms (e.g., beach ridges and spits) are essential archives of paleo-lakes evolution that can be studied with space imagery. This preliminary work over a selected area shows that very high resolution satellite imagery (i.e., Pléiades) is crucial to characterize the paleo-littoral of Megalake Chad and to understand its evolution through time and space, which in turn informs about the climate of the Sahara-Sahel region during the African Humid Period. This remote sensing study of the Goz Kerki paleo-spit requires now ground truth controls, with the acquisition of complementary data, notably to provide an absolute calendar (OSL, C14) for the evolution of the spit system and to characterize its stratigraphic architecture. A similar approach could be extended to the characterization of the whole littoral zone of Megalake Chad or at least to selected key-areas such as those already defined by Schuster et al. (2005), and could be applied to the study of numerous other large paleolakes (e.g., Turkana, Bonneville, Eyre, Aral). 


\section{Acknowledgements}

We are grateful to É. Boussarie, C. Tinel and D. Fontannaz from CNES for access to the Pléiades images (CCNES 2012, Airbus DS/ Spot Image) of the study area and for kind invitation to participate to «Pléiades Days 2014 » (Toulouse, France). MS thanks the CNRS/INSU-SYSTER, the Fondation Université de
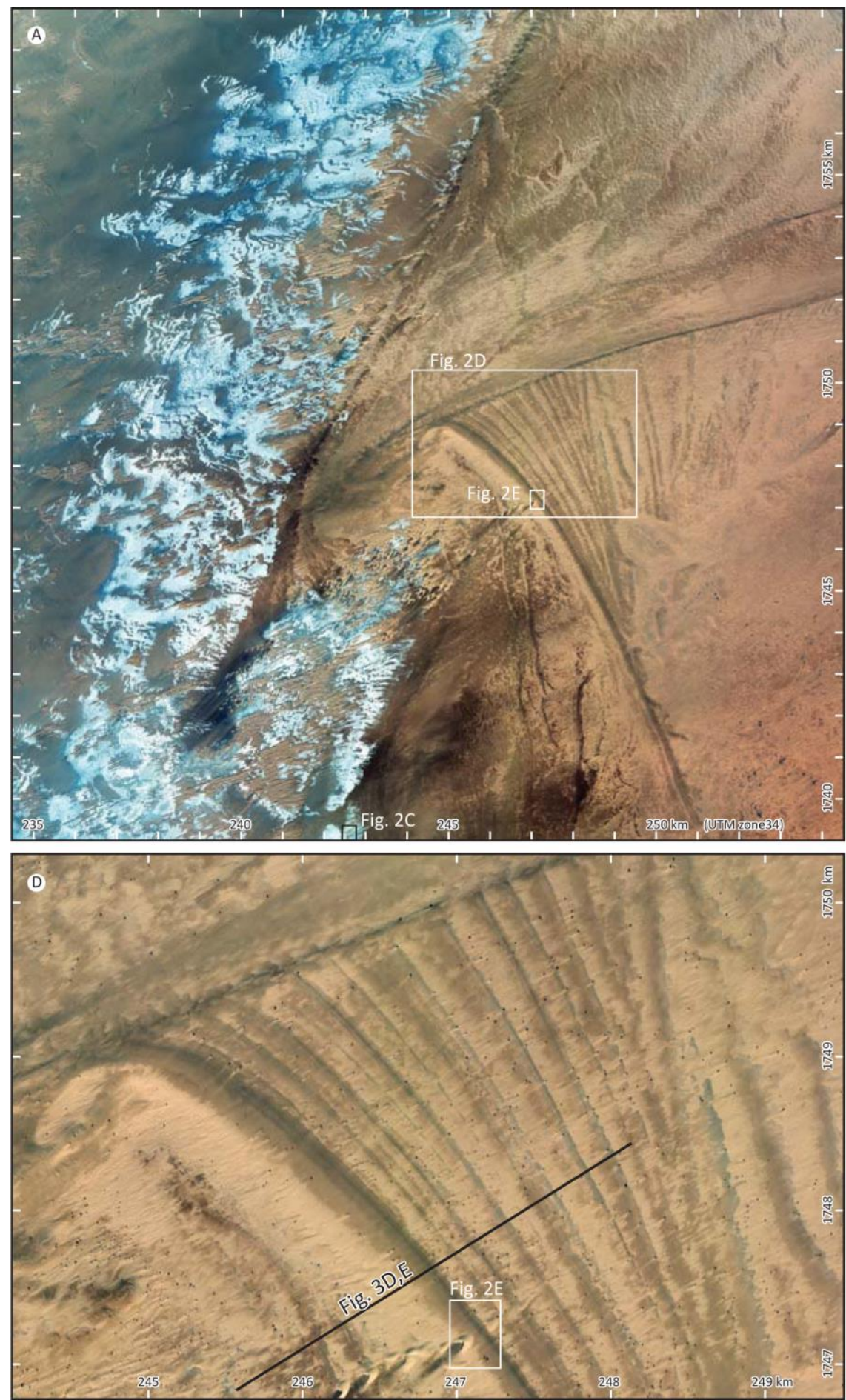

Strasbourg and the Cercle Gutenberg for research grants, as well as O. D'Hont (Ambassade de France, N'Djamena) and Moussa Isseini (Direction de la Recherche Scientifique et Technique, Tchad) for their kind support. Two anonymous reviewers are acknowledged for their constructive comments.
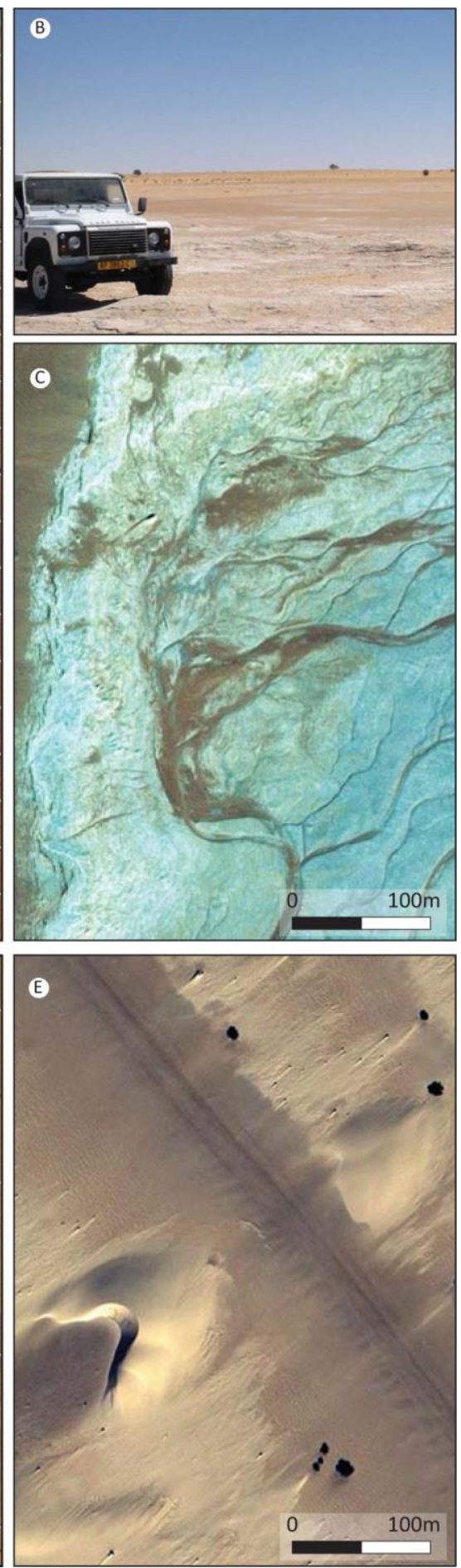

Figure 2: Pléiades image of the paleo-spit of the Goz Kerki. (A) Pléiades scene $(20 \times 20 \mathrm{~km})$. (B) Field view of the paleolittoral with wind-eroded diatomite layers in the foreground (paleo-lake offshore deposits) and massive sand ridge in the background (paleo-littoral zone) (Land Rover Defender for scale). (C) Paleo-drainage channels network resulting from post-lacustrine erosion of diatomites by ephemeral streams runoff. (D) Close view of the paleo-spit showing its terminal hook and a set of beach ridges. (E) Modern eolian landforms (barchan dunes, granule mega-ripples, nebkhas, sand sheets) can be identified on the spit strandplain, and vehicle tracks follow the darker deflation zone on its western side. 

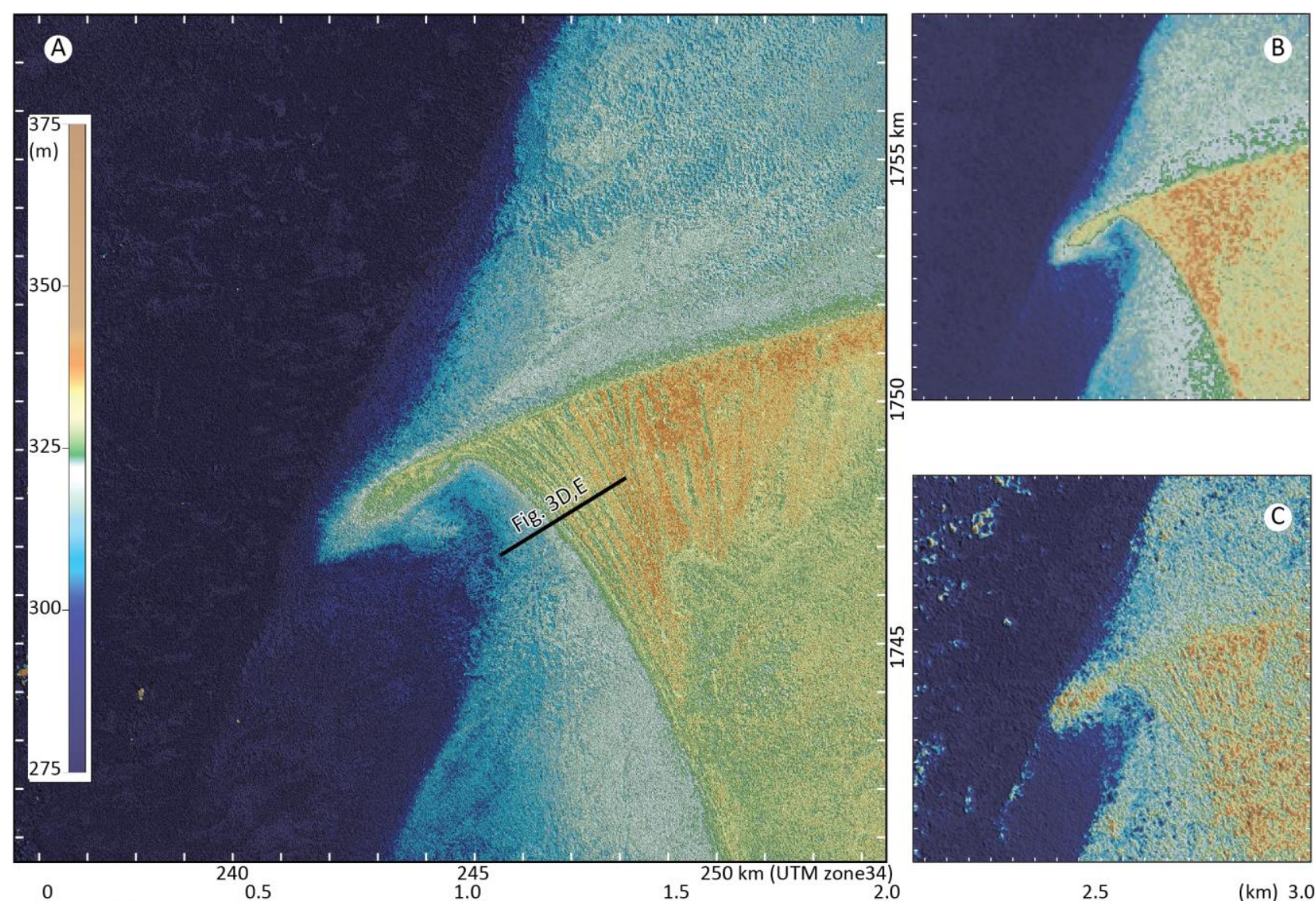

A
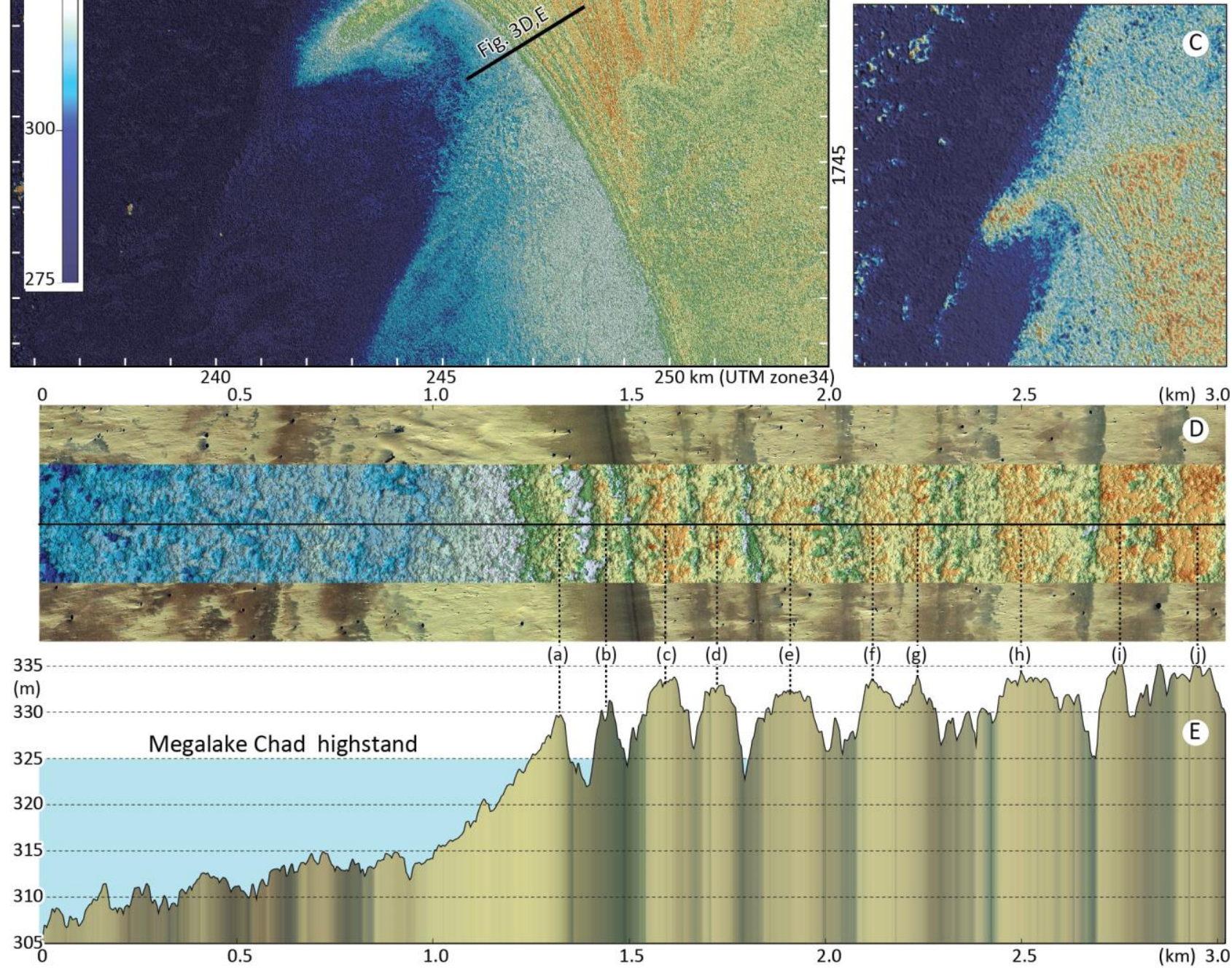

Figure 3: Shaded relief image of the Goz Kerki topography and paleo-bathymetry of Megalake Chad generated from the Pléiades stereoscopic DEM (A). (B) SRTM3 and (C) ASTERGDEM for comparison. (D) Combining optic image and DEM can improve the identification of beach ridges (light colors on optic image) and swales (dark colors on optic image); note that the penultimate ridge (b) could only be detected from the DEM. (E) Topographic profile revealing high-stand beach ridge crests $(c-j)$ at constant elevation (to the East) and the two last regressive beach ridges (a and b) at decreasing elevations (to the West).

\section{References}

Bard E., 2013. Out of the African Humid Period. Science 342, 808-809.

Bouchette F., Schuster M., Ghienne J.-F., Denamiel C., Roquin C., Moussa A., Duringer Ph., 2010.
Hydrodynamics in the Holocene Lake Mega-Chad. Quaternary Research 73, 226-236.

Callot Y., Fontugne M., 2008. Les sites lacustres d'âge holocène dans l'est du Grand Erg occidental (nordouest du Sahara algérien). Géomorphologie 3,187200 
Cohen A.S., 2003. Paleolimnology: The History and Evolution of Lake Systems. Oxford University Press, New York, 528p.

Contoux C., Jost A., Sepulchre P., Ramstein G., Krinner G., Schuster M., 2013. Impact of the Megalake Chad on climate and vegetation during the late Pliocene and the mid-Holocene. Climate of the Past 9, 1417-1430.

Damnati B., 2000. Holocene lake record in the Northern Hemisphere of Africa. Journal of African Earth Sciences 31, 253-262.

deMenocal, P.B., Tierney J.E., 2012. Green Sahara: African Humid Periods Paced by Earth's Orbital Changes. Nature Education Knowledge 3(10):12

Drake N., Bristow C., 2006. Shorelines in the Sahara: geomorphological evidence for an enhanced monsoon from palaeolake Megachad. Holocene 16, 901-911.

Durand A., 1995. Geomorphological records of neotectonics in the Lake Chad Basin: the changes in drainage pattern and the pseudo shoreline of Lake Megachad in Kadzell. C. R. Acad. Sci. 321, 223229.

Evans O.F., 1942. The origin of spits, bars and related structures. Journal of Geology 50, 846-863.

Fabre J., Petit-Maire N., 1988. Holocene climatic evolution at $22-23^{\circ} \mathrm{N}$ from two palaeolakes in the Taoudenni area (northern Mali). Palaeogeogr., Palaeoclimatol., Palaeoecol. 65, 133-148.

Gasse F., 2000. Hydrological changes in the African tropics since the Last Glacial Maximum. Quaternary Science Reviews 19, 189-211.

Ghienne J.-F., Schuster M., Bernard A., Duringer Ph., Brunet M., 2002. The Holocene giant Lake Chad revealed by Digital Elevation Models. Quaternary International 87, 81-85.

Kröpelin S., Verschuren D., Lezine A.-M., Eggermont H., Cocquyt C., Francus P., Cazet J.P., Fagot M., Rumes B., Russell J.M., Darius F., Conley D.J., Schuster M., Suchodoletz H., Engstrom D.R., 2008. Climate-Driven Ecosystem Succession in the Sahara: The Last 6000 Years. Science 320, 765769.

Kuper R., 2006. After 5000 BC: The Libyan desert in transition. C. R. Palevol 5, 409-419

Leblanc M., Favreau G., Maley J., Nazoumou Y., Leduc C., Stagnitti F., van Oevelen P.J., Delclaux F., Lemoalle J., 2006. Reconstruction of Megalake Chad using Shuttle Radar Topographic Mission data. Paleogeogr. Paleoclimatol. Paleoecol. 239, 16-27.

Le Quellec J.-L., 1999. Répartition de la grande faune sauvage dans le nord de l' Afrique durant l'Holocène. L'Anthropologie 103, 161-176.

Lezine, A.-M. 2009. Climatic history of the African and Arabian deserts. C. R. Geosciences 341, 569-574.

Maley J., 2004. Le bassin du Tchad au quaternaire récent : formations sédimentaires, paléoenvironnements et préhistoire : la question des paléotchads. In: Sémah A.-M. \& Renault-Miskovsky J. (Eds), L'évolution de la végétation depuis deux millions d'années. Artcom et Errance, Paris, 179217pp.

Olivry J.C., Chouret A., Lemoalle J., Bricquet J.P., 1996. Hydrologie du lac Tchad. ORSTOM Paris, 266p.

Pachur H.J., Kröpelin S. 1987. Wadi Howar: paleoclimatic evidence from an extinct river system in the southeastern Sahara. Science 237, 298-300.
Pachur H.J., Rottinger F., 1997. Evidence for large extended palaeolake in the eastern Sahara as revealed by spaceborne radar lab images. Remote Sensing of Environment 61, 437-440.

Paillou Ph., Schuster M., Farr T., Tooth S., Rosenqvist A., Lopez S., 2009. Mapping of a Major Paleodrainage System in Eastern Libya using Orbital Imaging Radar: The Kufrah River. Earth and Planet. Science Letters 277, 327-333.

Pias J., Guichard E., 1957. Origine et conséquences de l'existence d'un cordon sableux dans la partie sudouest de la cuvette tchadienne. C. R. Acad. Sci. 244, 791-793.

Pierrot-Deseilligny M., Paparoditis N., 2006. A multiresolution and optimization-based image matching approach: an application to surface reconstruction from SPOT5-HRS stereo imagery. IAPRS vol XXXVI-1/W41, ISPRS Workshop on Topographic Mapping from Space, Ankara, Turkey.

Pierrot-Deseilligny M., 2007. MicMac, un logiciel pour la mise en correspondance automatique d'images dans le contexte géographique. Bulletin d'Information Scientifique et Technique de I'IGN 77.

Pilkey O.H., Neal W.J., Kelley J.T., Cooper J.A.G., 2011. The world's beaches: a global guide to the science of the shoreline. University of California Press, Berkeley and Los Angeles, 283p.

Schneider J.-L., 1967. Évolution du dernier lacustre et peuplement préhistorique aux Pays Bas du Tchad. Bull. ASEQUA 14/15, 203-215.

Schuster M., 2002. Sédimentologie et paléoécologie des séries à vertébrés du paléolac Tchad depuis le Miocène supérieur. Thèse de doctorat de l'Université Louis Pasteur, Strasbourg I. 152p.

Schuster M., Duringer Ph., Ghienne J.-F., Vignaud P., Beauvilain A., Mackaye H.T., Brunet M., 2003. Coastal conglomerate around the Hadjer el Khamis inselbergs (western Chad, central Africa): new evidence for Lake Mega-Chad episodes. Earth Surface Processes and Landforms 28, 1059-1069. Schuster M., Roquin C., Duringer Ph., Brunet M., Fontugne M., Mackaye H.T., Vignaud P., Ghienne J.-F., 2005. Highlighting Holocene Lake Mega-Chad paleoshorelines from space. Quaternary Science Reviews 24, 1821-1827.

Schuster M., Duringer Ph., Ghienne J.-F., Roquin C., Sepulchre P., Moussa A., Lebatard A.-E., Mackaye H.T., Likius A., Vignaud P., Brunet M., 2009. Chad Basin: paleoenvironments of the Sahara since the late Miocene. C. R. Geosciences 341, 612-620.

Sereno P.C., Garcea E.A.A., Jousse H., Stojanowski C.M., Saliège J.-F., et al., 2008. Lakeside Cemeteries in the Sahara: 5000 Years of Holocene Population and Environmental Change. PLoS ONE 3(8): e2995. doi: 10.1371/journal.pone.0002995

Sepulchre P., Ramstein G., Schuster M., 2009. Modelling the impact of tectonics, surface conditions and Sea Surface Temperatures on Saharan and sub-Saharan climate evolution. C. R. Geosciences 341, 603-611.

Sepulchre P., Schuster M., Ramstein G., Krinner G., Girard J.-F., Fluteau F., Vignaud P., Brunet M., 2008. Evolution of Lake Chad Basin during the midHolocene: a preliminary approach from lake to climate modeling. Global and Planetary Change 61, 41-48.

Tilho J., 1925. Sur l'aire probable d'extension maxima de la mer paléotchadienne. C. R. Acad. Sci. 181, 643-646. 